\title{
PEMBINAAN KADER POSYANDU WILAYAH KECAMATAN SINGAPARNA TAHUN 2017
}

\author{
OLEH :
}

Sinta Fitriani, SKM, MKM

Chanty Yunie Hartiningrum, SST, M.Kes

\section{A. DASAR PEMIKIRAN}

Kondisi pembangunan kesehatan diharapkan telah mampu mewujudkan kesejahteraan masyarakat yang ditunjukkan dengan membaiknya berbagai indikator pembangunan sumber daya manusia, seperti meningkatnya derajat kesejahteraan dari status gizi masyarakat, meningkatnya kesetaraan gender, meningkatnya tumbuh kembang optimal, kesejahteraan dan perlindungan anak, terkendalinya jumlah dan laju pertumbuhan penduduk, serta menurunnya kesenjangan antar individu, antar kelompok masyarakat dan antar daerah dengan tetap lebih mengutamakan pada upaya preventif, promotif serta pemberdayaan keluarga dan masyarakat dalam bidang kesehatan. Salah satu bentuk upaya 2 pemberdayaan masyarakat di bidang kesehatan adalah menumbuh kembangkan Posyandu (Menkes RI, 2011:2).

Posyandu merupakan salah satu bentuk Upaya Kesehatan Bersumberdaya Masyarakat (UKBM) yang dikelola dan diselenggarakan dari, oleh, untuk dan bersama masyarakat dalam penyelenggaraan pembangunan kesehatan, guna memberdayakan masyarakat dan memberikan kemudahan kepada masyarakat dalam memperoleh pelayanan kesehatan dasar, utamanya untuk mempercepat penurunan angka kematian ibu dan bayi. Sejak dicanangkannya Posyandu pada tahun 1986, berbagai hasil telah banyak dicapai. Angka kematian ibu dan kematian bayi telah berhasil diturunkan serta umur harapan hidup rata-rata bangsa Indonesia telah meningkat secara bermakna (Menkes RI, 2011:2-3).

Posyandu adalah salah satu bentuk Upaya Kesehatan Bersumber Daya Masyarakat (UKBM) yang dikelola dan diselenggarakan dari oleh untuk dan bersama masyarakat dalam penyelenggaraan pembangunan kesehatan. Posyandu bertujuan memberdayakan dan memberikan kemudahan kepada masyarakat dalam memperoleh pelayanan kesehatan dasar untuk mempercepat penurunan angka kematian ibu dan bayi. Ditinjau dari aspek kualitas ditemukan banyak masalah di posyandu, antara lain kelengkapan sarana dan keterampilan kader yang belum memadai, cakupan kegiatan masih rendah, cakupan anak usia di bawah dua tahun masih di bawah $50 \%$, sedangkancakupan ibu hamil hanya sekitar 20\% (DepartemenKesehatan R1, 2006).

Masih sedikitnya jumlah posyandu mandiri saat ini menunjukkan belum optimalnya kinerja posyandu. Halini tampak dari strata posyandu di Indonesia (tahun2004) yakni 33,61\% posyandu pratama, $39,86 \%$ posyandu madya, 
$23,62 \%$ posyandu purnama,dan posyandu mandiri $(2,91 \%)$.

Berdasarkan data yang didapat dari profil Kabupaten Tasikmalaya Posyandu yang berada di Wilayah Kabupaten Tasikmalaya 2.282 unit, Posyandu yang berada di wilayah kerja Puskesmas Singaparna terdapat 40 posyandu tahun 2017.

STIKes Respati sebagai satusatunya sekolah tinggi ilmu kesehatan di Kabupaten Tasikmalaya memiliki tanggung jawab untuk memberikan kontribusi terhadap permasalahan terkait dengan kesehatan di Kabupaten Tasikmalaya melalui kegiatan Tri Dharma Perguruan Tinggi salah satunya dengan kegiatan pengabdian kepada masyarakat. Salah satu upaya nyata STIKes Respati adalah dengan melaksanakan kegiatan pengabdian kepada masyarakat dengan pendampingan Kader Posyandu sebagai upaya peningkatan status gizi untuk dapat membantu terwujudnya kesehatan masyarakat secara umum dan perbaikan status gizi secara khususnya.

Tujuan kegiatan ini dilakukan untuk meningkatkan peran kader

\section{SASARAN}

Sasaran kegiatan ini adalah seluruh kader posyandu yang berada di Wilayah Kecamatan Singaparna

\section{E. TEMPAT DAN WAKTU}

Kegiatan dilaksanakan di Ruang Demonstrasi Laboratorium Respati dan dilaksanakan pada Hari Kamis Tanggal 30 November 2017 posyandu dalam menjalankan tugas kadernya baik di hari pelaksanaan maupun di luar hari pelaksanaan.

\section{B. TUJUAN}

Tujuan kegiatan ini dilakukan untuk meningkatkan peran kader posyandu dalam menjalankan tugas kadernya baik di hari pelaksanaan maupun di luar hari pelaksanaan.

\section{BENTUK KEGIATAN}

Bentuk kegiatan yang dilakukan adalah sebagai berikut ini :

1. Pendataan jumlah kader

2. Survei kemampuan kader dalam melaksanan tugasnya

3. Diskusi kelompok beserta pihak terkait

4. Pelatihan kader baik teori maupun praktek

5. Perlombaan simulasi peran dan tugas kader posyandu

6. Evaluasi

\section{F. HASIL KEGIATAN}

1. Pendataan jumlah kader Pendataan jumlah kader diperoleh langsung dari bagian gizi Puskesmas Singaparna. Diperoleh jumlah kader dari masing masing desa.

Acara pembinaan kader diikuti oleh 10 posyandu dengan jumlah kader 5 orang per posyandu.

2. Survei kemampuan kader dalam melaksanakan tugasnya

Kegiatan pembinaan diawali dengan pemberian pre test pengetahuan kader tentang peran dan fungsi kader di posyandu. 
Untuk kegiatan survey keterampilan kader dilakukan observasI pelaksanaan posyandu dengan simulasi kegiatan posyandu.

3. Pembinaan kader posyandu Pemberian materi tentang tugas dan fungsi kader posyandu.

4. Perlombaan peran dan fungsi kader posyandu

Kegiatan ini dilaksanakan di Kampus STIKes Respati dengan diikuti oleh 10 kelompok kader posyandu.

Penilaian dilakukan oleh tim dosen dan pemegang program gizi Puskesmas Singaparna.

Pemenang lomba kader adalah :

Juara I : Posyandu Cigorowek Juara II : Posyandu Margamulya

\section{H. DAFTAR PUSTAKA}

\section{DAFTAR PUSTAKA}

Departemen Kesehatan RI Pedoman Umum Pengelolaan Posyandu Jakarta . 2006.

Pokjunal Posyandu, Pedoman Pengelolaan Posyandu Jakarta : Pokjunal Posyandu : 2006

Dodo.D. Faktor -Faktor yang Berhubungan dengan Keaktifan Kader dalam Pelaksanaan Kegiatan Posyandu di Kelurahan : Jurnal Pangan, Gizi dan Kesehatan Tahun 1, vol 1, no 1 April 2009
Juara III : Posyandu Babakan Karang II Singaparna

\section{G. KEPANITIAAN}

Kegiatan dilaksanakan oleh Dosen Program Studi S1 Kesehatan Masyarakat dan Diploma III Kebidanan serta oleh mahasiswa STIKes Respati. Adapun pelaksana kegiatan tersebut adalah :

1. Sinta Fitriani, SKM, MKM

2. Chanty YH, SST, M.Kes

3. Tati Maryati

4. Yunita Puteri

5. Aty Hermawati

6. Mahasiswa D III Kebidanan

7. Mahasiswa S1 Kesehatan Masyarakat

Depkes RI. Pengertian Posyandu, Jakarta. 1991.

Departemen Kesehatan RI. Pengertian Kader. Jakarta.2009.

Jurnal Manajemen Pelayanan Kesehatan. Vol 13 no 4 : Des. 2010.

Departemen Kesehatan RI. Revitalisasi Posyandu Direktorat Kesehatan Komunitas. Jakarta. 2005.

Kementrian Kesehatan RI. Buku Panduan Kader Posyandu. Jakarta 2011. 


\section{J. DOKUMENTASI}
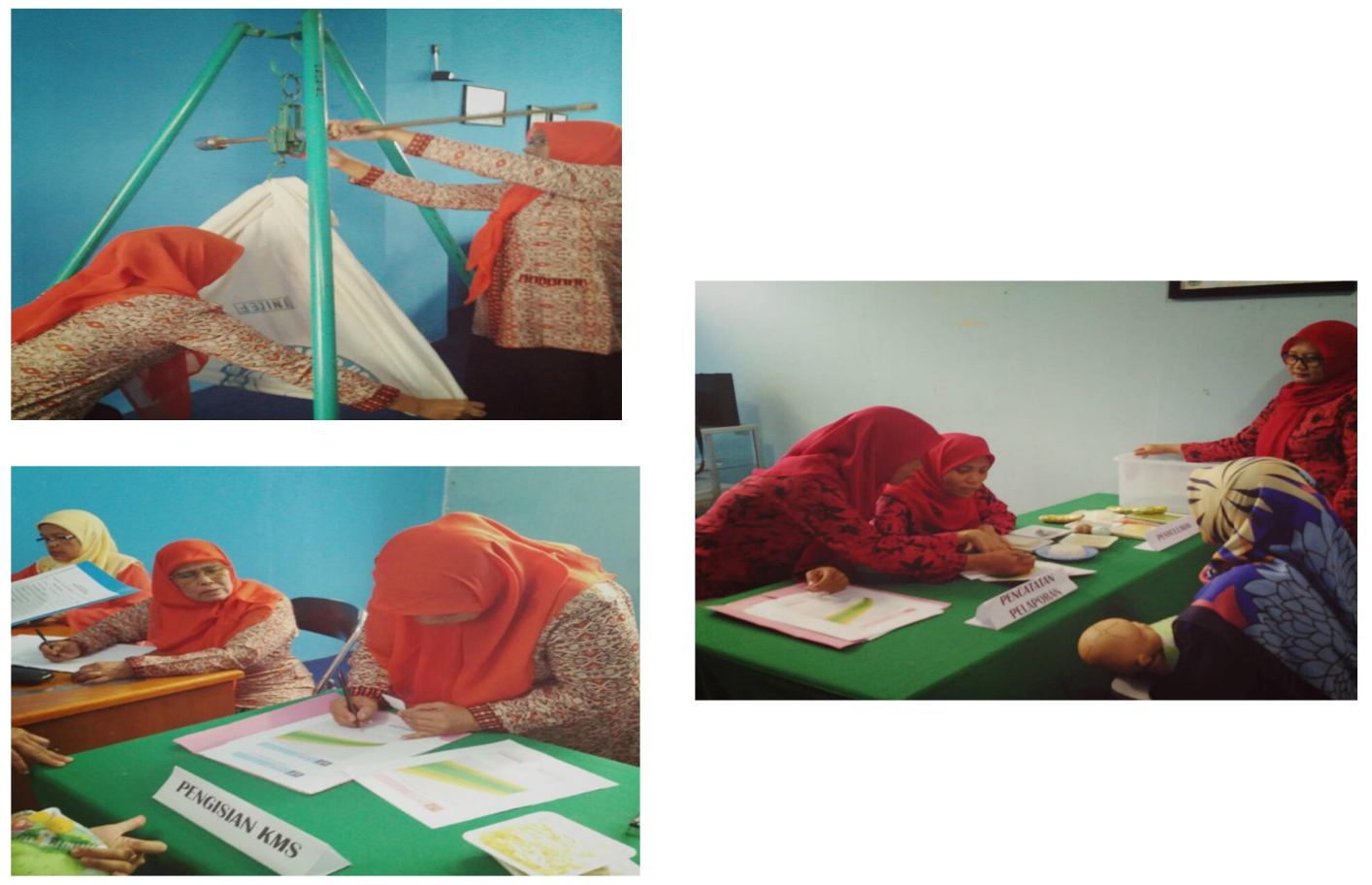

Gambar: Simulasi pelaksanaan posyandu 